\title{
The Adaptation of Intentional Immigrant Entrepreneurs: A Case Study
}

\author{
Prue Cruickshank, Ann Dupuis
}

\begin{abstract}
A B S T R A C T
Objective: This paper describes the experiences of a group of intentional immigrant entrepreneurs (IIEs) who have successfully set up a business within three years of arrival in a new country. It shows how various forms of symbolic capital are successfully deployed at each stage of the entrepreneurial process and asserts that the study of intentional, well-resourced immigrants, can contribute to understanding immigrant entrepreneurs' adaptation to their new settings and also inform immigration policy.
\end{abstract}

Research Design \& Methods: Qualitative in-depth interviews were conducted with a sample of New Zealand intentional immigrant entrepreneurs. The iterative analytical process used revealed the various dimensions of symbolic capital necessary for adaptation to the host country and to fulfilling visa requirements to gain residency.

Findings: This paper demonstrates that the successful adaptation of IIEs, while in the first instance requiring adequate financial capital, also requires the strategic use of human, cultural and social capital, in different ways and at different times in the entrepreneurial process, to overcome the obstacles and barriers to success.

Implications \& Recommendations: As immigration policy makers seek to balance global migrant pressures and international obligations against internal national economic and political demands, the results of this study could resonate with both global policy analysts and scholars engaged in immigrant entrepreneurship.

Contribution \& Value Added: This article adds to the relatively small body of scholarship on IIEship, particularly those who, unlike the majority of immigrant entrepreneurs, do not establish a business within ethnic communities.

\begin{tabular}{ll}
\hline Article type: & research paper \\
& intentional immigrant entrepreneurs; forms of capital; immigrant \\
Keywords: & entrepreneur adaptation; entrepreneur visas; entrepreneurship \\
& models
\end{tabular}

JEL codes: $\quad$ L26, F22

Received: 31 May 2015 Revised: 3 September 2015 Accepted: 15 September2015

\section{Suggested citation:}

Cruickshank, P., \& Dupuis, A. (2015). The Adaptation of Intentional Immigrant Entrepreneurs: A Case Study. Entrepreneurial Business and Economics Review, 3(3), 77-93. doi: 10.15678/EBER.2015.030305 


\section{INTRODUCTION}

There is a large and growing body of literature on the complex phenomenon of immigrant entrepreneurship. One end of the immigrant entrepreneurial spectrum captured in this literature is represented by immigrant business activities which return low profits under difficult labour conditions (Rath, 2000). The other end is represented by highly skilled, intentional well-resourced immigrant entrepreneurs (Marger, 2001a; Saxenian, 2002), who form a distinctive but minimally studied niche group. The characteristics that set intentional immigrant entrepreneurs (IIES) apart is that a) on arrival in the host country they are well-resourced and b) their ability to gain residence in their host country is dependent on their success in establishing a business. Hence, the two features of adequacy of resources and intentionality in defining IIEs (Cruickshank, 2013). Given the potential of IIEs to contribute to the economy of their host country through wealth and employment creation, and innovation (Curci \& Mackoy, 2010), under conditions where they, rather than the government bear the risks, their adaptation to their new environment is a matter of significant importance to governments as they increasingly seek to attract this group.

This article presents a model for the successful adaptation of IIEs to their selected host country. The model was developed from a study of IIEs to New Zealand (Cruickshank, 2013), a country which, like many similar countries, has introduced specific visa options to attract suitable immigrants as a means of addressing issues of population and economic growth. One such option, the Long Term Business Visa (LTBV), introduced in 1999, was intended to provide a conditional, structured opportunity for immigrants who did not meet the criteria of the more commonly used skilled migrant or investor visa categories. Under the LTBV conditions, applicants were given three years to establish and actively operate a business which, if deemed successful, would qualify them for residence in New Zealand as an Entrepreneur. Visa conditions required these immigrant entrepreneurs to be well resourced and demonstrate intentionality. Furthermore, as the immigrant's business was required to benefit New Zealand by introducing new technologies, skills, products, services, export markets, create employment or revitalize an existing business (New Zealand Immigration Service, 2006, s 51-1), innovation was both implied and required. Hence the definition of an IIE is extended to include the entrepreneurial characteristics of identification and exploitation of a market opportunity involving an aspect of innovation. IIEs can be differentiated from immigrant investors who obtain visas by investing significant economic capital through a host country enterprise or enterprises, but need not necessarily be involved in those enterprises.

The immigrant entrepreneur adaptation model is broken down into three stages, each fundamental to the entrepreneurial process: the preparation stage; the implementation stage; and the consolidation/expansion stage. In the preparation stage applicants had first to identify a suitable visa. They then needed to complete a visa application which included a business plan. Once their plans were approved a nine month visa was granted to enable applicants to implement their business plan. If they were deemed to have taken reasonable steps towards business implementation, their visas were extended for the remaining 27 months of the LTBV three year visa. During this final stage applicants consolidated or expanded their businesses so that at the end of the three year 
period they had met all the required conditions to gain residency. If applicants did not meet the criteria at each stage their visa was not renewed.

We argue that the three stages of the entrepreneurial adaptation model can apply broadly, regardless of the characteristics of individual entrepreneurs, the businesses in which they are involved, or whether or not they need to fulfill any specific conditions, like those pertaining to the LTBV. The value of examining these stages as they apply to the LTBV has to do with the range of conditions, especially the specific time requirements, associated with the Visa itself. That the applicants can meet these stringent conditions in such a compressed time period highlights the factors necessary for entrepreneurial enterprises more generally. These factors comprise forms of capital or resources, drawn on to achieve a successful, timely, business outcome. We suggest that the model presented can be used to analyze the successful adaptation of all successful immigrant entrepreneurs to their host country and can be applied in contexts well beyond New Zealand to help explain successful entrepreneurship.

In the following sections we first review two distinct sets of literature on the adaptation of immigrant entrepreneurs to their host country and forms of capital. We then discuss the qualitative methodological approach to the research on which this article is based and the methods used for data gathering and analysis. The subsequent section sets out the research results focusing on the particular forms of capital that were drawn on as a resource to overcome the particular obstacles met at each of the three stages of the entrepreneurial process delineated in the model. In the final section the conclusions from the study are drawn and the broad implications of the findings are discussed. We conclude that the study of IIEs, which has only received very limited attention, can contribute new knowledge to the literature on the adaptation of immigrant entrepreneurs to their host society and also inform policy makers responsible for attracting this distinctive and increasingly important group.

\section{LITERATURE REVIEWAND}

This article is informed by two distinct sets of literature: literature pertaining to immigrant entrepreneurs and adaptation issues in their new host country; and literature on forms of capital. Each of these literature strands is crucial to the understanding of the successful, timely adaptation of immigrant entrepreneurs.

\section{Locating Intentional Immigrant Entrepreneurs}

Locating IIEs within the broader immigration and entrepreneurship literature is depicted in Figure 1. Migration is a complex and multi-dimensional phenomenon that affects the communities and economies of both host countries and countries of origin in diverse ways. Because of this complexity migration research is an extensive area, attracting contributions from a range of disciplines. The migration literature drawn on for this article focuses on the structural level, and discusses the way influential global and national economic factors affect migration regulations, patterns and policies (Castles \& Miller, 2009). The work on business immigrants is more specific, including skilled and unskilled immigrants and investors and entrepreneurs. More specific again, is the work on underresourced immigrant and/or ethnic entrepreneurs. The fourth area on immigrant entrepreneurs relates to adequately resourced IIEs (Figure 1). 
Following Castles and Miller (2009), two strands within migration theory inform insights into the structural influences on the participants in this study. A dominant theoretical paradigm in migration studies, neoclassical theory, emphasizes rational, individualistic migration decision-making, as migrants purposefully select their destination country. IIEs fit this description as they carefully select their destination country to improve the future quality of life for themselves and their families. Also pertinent is the migration systems theory which involves both macro and micro factors, and describes two or more countries in on-going historical migration relations such as New Zealand and Great Britain. This theory incorporates the individualist selection processes typical of the participants in this study, while incorporating macro-structural dimensions such as national immigration policies, including the LTBV option.

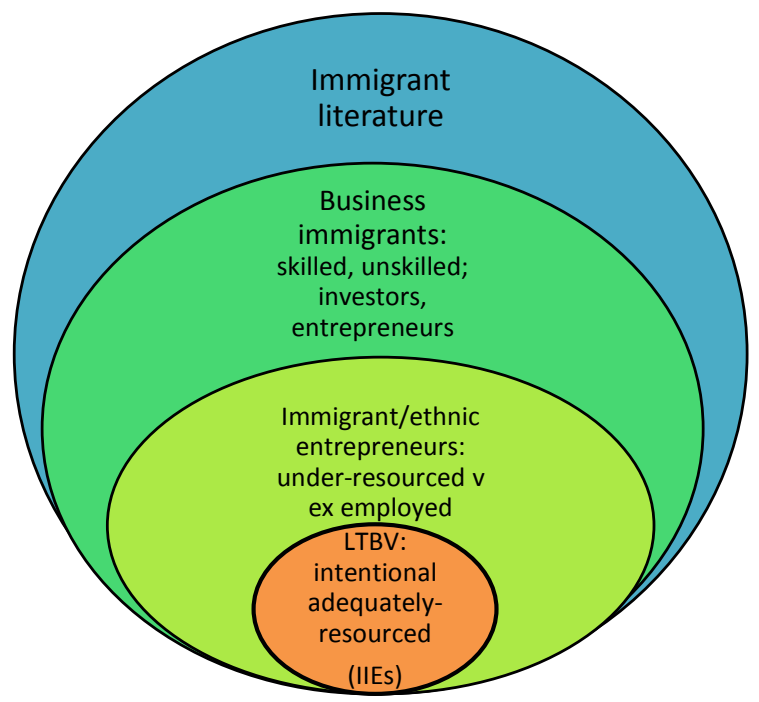

Figure 1. Location of LTBV holders within business immigrant studies Source: Cruickshank (2013).

Business immigration literature incorporates economic and regulatory perspectives of immigrant business investors and entrepreneurs, including the employment of skilled and unskilled labour (Rath, 2000). In the post-WW2 period, research on business immigrants was dominated by American researchers, reflecting that country's economic and regulatory environment and its institutional and national conceptions and assumptions (Aldrich \& Waldinger, 1990; Portes, 1998; Waldinger, Aldrich \& Ward, 1990). Moving forward into the 21st century, immigrant entrepreneurship research has become more geographically diversified (Collins, 2008; Dana, 2007; Kloosterman \& Rath, 2003), providing a broader range of cultural and national perspectives.

Located within the business immigrant sector, is the immigrant or ethnic entrepreneurial literature. One strand within this literature focuses on the less-resourced or unintentional entrepreneurs who might or might not possess the types of skills sought in the host society. They might also seek employment as their first option, only to be pushed reluctantly into entrepreneurship when faced with few employment opportunities. Early 
studies of immigrant and ethnic entrepreneurship generally, focused on unintentional entrepreneurs, driven from poorer to richer countries for economic reasons who, when unable to find employment in the host country, survived by starting both formal and informal enterprises (Kloosterman, 2000; Light, 2004; Volery, 2007).

By contrast, a second and more recent strand in the business immigrant studies literature centers on adequately-resourced IIEs, the focus of this study. IIEs are very likely to have a background of self-employment and arrive in their adopted country with sufficient resources to fulfill their intention to establish a business (Collins, 2008; Ley, 2006; Marger, 2001c). For example, studies of ethnic minority entrepreneurs in Canada, Europe and Australia described the establishment of ethnic communities and businesses which helped revitalize metropolitan areas (Kloosterman \& Rath, 2003). Other studies focused on skilled ethnic minority immigrant employees who later set up businesses (Basu, 2004; Collins, 2008; Kloosterman \& Rath, 2003; Kloosterman, van der Leun \& Rath, 1999; Light, 2004), such as Chinese and Indian entrepreneurs in Silicon Valley (Saxenian, 1999, 2002).

The dichotomy of, on the one hand, under-resourced and unintentional entrepreneurship and on the other, well-resourced and intentional entrepreneurship, can be linked to, but can also be differentiated from necessity-based and opportunity-driven entrepreneurship and from the strand of literature which focuses on transnational ties and business success (Brzozowski, Cucculelli \& Surdej, 2014). While IIEs can embed themselves within their ethnic communities, many choose not to do so and function within the mainstream market, as demonstrated by many LTBV holders in this study. While some IIEs maintain transnational ties, others largely operate within the host country's economy. Curci and Mackoy (2010) provide a useful typology of immigrant enterprises in terms of mainstream market or enclave positioning. Pertinent to this research too have been studies that show divergent degrees of success among IIEs (see e.g. Hiebert, 2008), although for those who entered countries like Canada, the open ended conditions on their visas and the lack of governmental monitoring of visa conditions has led to some less than satisfactory outcomes (Marger, 2006).

\section{Economic and Symbolic Capital}

Significant to this study is the role of capital, both economic and symbolic. Following Bourdieu (1986), symbolic capital includes human, cultural and social capital. Extending the analysis of the success of IIEs to include both economic and symbolic capital allows for an integrative theory of adaptation which incorporates structural dimensions with the creativity and freedom of agency (Brubaker, 1985). Broadly, capital, in whatever form, represents a resource created by an investment of time and energy by economic agents and is regarded as essential to many forms of success in society.

As entrepreneurs require adequate finance to underwrite their enterprise (Boissevan, et al., 2006), the availability and use of finance represents one of several key considerations when analyzing the outcomes of entrepreneurial activity (Frederick, Kuratko, \& Hodgetts, 2007). Financial capital enables immigrant entrepreneurs to acquire premises and stock and provides a cash-flow until the business becomes financially sustainable. To fund new businesses, entrepreneurs usually obtain financial capital from their savings, family, or less often, through financial partners, investors, stockholders, or via a bank loan (Frederick, Kuratko \& Hodgetts, 2007). Although some immigrants embedded in co- 
ethnic communities can generate adequate capital (Ndofor \& Priem, 2011), they often struggle to do so (Boissevan et al., 2006). In contrast, IIEs are adequately self-funded financially (Marger, 2001a; New Zealand Immigration Service, 2002).

While there is a substantial literature on the financial aspects of immigrant entrepreneurship, comparatively little has been written which focuses on the role of symbolic capital in successful immigrant entrepreneur adaptation to the host society. Bourdieu's (1986) analysis of the forms, functions, conversion, acquisition, objectivity and subjectivity of capital, is useful in analyzing the resourcing of IIE's businesses. In his analysis of the transference of economic wealth between generations, Bourdieu described the complementary forms of capital required to achieve a successful economic transfer. The value of Bourdieu's insight to this study is that these forms of symbolic capital enable IIEs to successfully engage in a capital transfer process, to facilitate their start-up business and support their establishment and expansion.

In constructing his theory of symbolic capital, Bourdieu recognized that the physical, material world is perceived through a cultural lens (Brubaker, 1985), an insight pertinent to this study as immigrants and members of the host society might perceive the value of their respective symbolic capital resources quite differently. It is therefore crucial for IIEs to ensure they understand the business environment in the host society and the attitudes and values of host society members. Successful adaptation of IIEs rests on their ability to skillfully deploy their forms of capital in ways appropriate to their new environment.

Cultural capital is a crucial dimension of IIE success. In its objectified form (such as cultural goods), institutionalised form (like recognised qualifications), or embodied form (such as attitudinal characteristics and dispositions), cultural capital is drawn on by IIEs as they negotiate and adapt to their new environment. Human capital, defined as measurable skills and capabilities to increase productivity (Becker, 1975), can be extended to include the value of such attitudes as innovation, creativity and experience, again vital dispositions IIEs bring to their successful adaptation. Studies of IIEs have recognized the importance of human capital to their successful settlement (Collins, 2004; Kloosterman \& Rath, 2001; Ley, 2006; Marger, 2001b). Appropriate human capital enables IIEs to research and strategically network to access mainstream markets, even when not fluent in the local language (Ley, 2006; Marger, 2001a, 2001c; Sequeira \& Rasheed, 2004).

The concept of social capital, described by Bourdieu (1986) as the value obtained by individuals through networked family, professional and social relations, has the capacity to recognize that individuals' active participation in relevant networked groups can provide access to finance, investment possibilities, innovations, information or new markets. Some theorists (Coleman, 1988; Loury, 1977, 1981; Putnam, 1995, 2000) expanded the notion of social capital beyond the individual to the broader community to recognize networks as a collective resource. The literature on immigrant and ethnic entrepreneurship recognizes the significance of social networks to the success of individual immigrant entrepreneurs and the communities they join (Aldrich \& Waldinger, 1990; Kloosterman, van der Leun \& Rath, 1999; Perreault et al., 2003). Networked social capital has both positive and negative dimensions. Putnam (2000) identified that norms, trust and solidarity can arise from community networks, when coordinated for mutual benefit. How- 
ever, immigrants, who do not engage with their neighborhoods for various reasons, could be excluded from such benefits (Putnam, 1995, 2000).

\section{MATERIAL AND METHODS}

Quantitative and qualitative approaches to immigrant entrepreneurial research each provide different ontological and epistemological assumptions of the social worlds which influence research design (Collis \& Hussey, 2009). In New Zealand, for example, quantitative research has provided useful trend data on LTBV holders (Department of Labour, 2004, 2005; Merwood, 2006; New Zealand Department of Labour, 2012). However, to explore the adaptation experiences of LTBV holders that lead to their success, requires a qualitative approach to capture the realities of immigrant entrepreneurs and provide insights into their world views. The distinctive behavior and success of IIEs is reliant on their responses to the problems they encounter and within the time constraints they have to work under. Quantitative methodologies cannot adequately reveal the depth of thinking and the rationalization processes underpinning their behavior. Conversely, a qualitative approach can explore participants' feelings, aspirations, motivations and attitudes and afford them an opportunity to reflect on their experiences. The particular method of in-depth interviews undertaken for this study ensured participants could reveal the way they constructed their experiences, in their own way and in their own words (Denzin \& Lincoln, 2005).

As IIEs represent a diversity of backgrounds, are indistinguishable from the general population, and have spent different lengths of time in New Zealand, this research required a sample selection process that would include in the sample entrepreneurs who had faced similar external circumstances in establishing their businesses. The LTBV allowed for this as it provided both a sample frame of potential research participants and a framework through which success could be gauged, in that gaining residency indicated success.

Entrepreneurial immigrants to New Zealand have proved typically reluctant to participate in surveys (Bascand, 2008; Wallis, 2006; Badkar, 2006; New Zealand Immigration Service, 2002), so the government was interested in the results of this study as the efficacy of the LTBV was under review. Approval was obtained from the appropriate government department to approach the 370 respondents to a government survey of 1585 LTBV holders, to signal their interest in participating in this research. Of the 370 initially 35 expressed an interest, with 16 finally consenting to being interviewed. Unlike quantitative research where the number of responses is crucial for generalizability, a sample size of 16 was adequate for a case study design where the major consideration is the indepth nature of the information gathered and the flexibility of participants to narrate their experiences in a way meaningful to them, not in a manner constructed by the researcher.

With respect to particpants' characteristics, nine were from the United Kingdom, three from the United States of America, two from South Africa and one each from China and Korea. Thirteen were male and three female, and all but two were married. All interviews were conducted in English and while all particpants spoke English, four were bilingual with three of these participants having English as a second language. Uncharacteristically, the participants were scattered around New Zealand with only three settled in 
Auckland, the main immigrant city where nearly 40 per cent percent of residents were born overseas (Statistics New Zealand, 2014).

The in-depth, semi-structured interviews were guided by a topic map, or interview schedule, to ensure that the three stages of the LTBV process were fully discussed. Participants initially provided a personal profile outlining their business background, education, experience and language ability, their perceptions of their levels of self-confidence, risk taking and desire for autonomy, and their motivations for coming to New Zealand. Through asking open ended questions and following a conversation-type interview approach, participants were then asked to talk about; their preparation before coming to New Zealand; their experiences in New Zealand of their first, second and third years; aspects of their business; looking back and reflecting on their experiences; looking forward and future business prospects; and their observations regarding the adaptation to the host country of any other LTBV holders they knew. The distinction between a conversation and an in-depth conversation-type interview lies in the focus on the participant rather than the researcher. Thus the researcher listens more and talks less (Seidman, 1991). Describing this type of interview as conversational in type, stresses that it flows and has the informality of a conversation, and that while it is not a question and answertype interview, it nevertheless elicits understandings on a topic of concern to the interviewer. All the interviews were recorded and later transcribed in preparation for data analysis.

After trialing several approaches to data analysis, the heuristic use of a number of frameworks was decided upon. Initially Bolton and Thompson's (2004) Entrepreneurial Process framework, which had been used to inform the interview topic map, was applied and Waldinger, Aldrich, and Ward's (1988) Interactive Theory of Ethnic Entrepreneurship was adapted for considerations of structure and agency. Particularly relevant was Volery's (2007) Enhanced Interactive Ethnic Entrepreneurship framework to suggest various dimensions of human, cultural and social capital. Each framework significantly revealed further dimensions in the patterns of symbolic capital used by the immigrant entrepreneurs. The iterative analytical process gradually revealed the various dimensions of human, cultural and social capital that were significant at each LTBV stage, despite the participants' differences in ethnic and social backgrounds, and their scattered locations across New Zealand. The data gathering and analysis process culminated in a revised IIE process framework (Figure 2) which highlights participants' strategies of adroitly drawing on their resources of economic and symbolic capital to meet the demands of the visa requirements and overcome the frequent barriers they met in the entrepreneurial process.

\section{RESULTS AND DISCUSSION}

This part of the paper sets out the key results of the research in three subsections, each of which represents a stage in the entrepreneurial process: preparation; implementation and expansion or consolidation. In each subsection the focus is on the way IIEs used the particular forms of capital that were most important at that stage (Figure 2). The value of Bourdieu's (1986) concept of symbolic capital integrating agency and structure to entrepreneurial immigration scholarship became evident during the analysis of the interviews. Symbolic capital incorporates the elements of a number of theories relevant to this study 


\begin{tabular}{|c|c|c|c|c|c|c|c|c|c|c|c|c|}
\hline \multicolumn{13}{|c|}{ Entrepreneurial Process } \\
\hline Stages & \multicolumn{4}{|c|}{ Preparation } & \multicolumn{4}{|c|}{ Implementation } & \multicolumn{4}{|c|}{ Expansion } \\
\hline $\begin{array}{l}\text { Financial } \\
\text { capital }\end{array}$ & \multicolumn{4}{|c|}{$\begin{array}{l}\text { Enterprise \& Living costs } \\
\text { Adequate }\end{array}$} & \multicolumn{4}{|c|}{$\begin{array}{l}\text { Enterprise \& Living costs } \\
\text { Adequate }\end{array}$} & \multicolumn{4}{|c|}{$\begin{array}{l}\text { Enterprise \& Living costs } \\
\text { Adequate }\end{array}$} \\
\hline \multirow{2}{*}{$\begin{array}{l}\text { Human } \\
\text { capital }\end{array}$} & $\begin{array}{c}\text { Industry } \\
\text { knowledge }\end{array}$ & $\begin{array}{r}\mathrm{M} \\
\text { kno }\end{array}$ & dge & $\begin{array}{c}\text { Business } \\
\text { knowledge }\end{array}$ & $\begin{array}{l}\text { Industry } \\
\text { knowledge }\end{array}$ & & $\begin{array}{l}\text { ket } \\
\text { edge }\end{array}$ & $\begin{array}{l}\text { Business } \\
\text { knowledge }\end{array}$ & $\begin{array}{l}\text { Industry } \\
\text { knowledge }\end{array}$ & $\begin{array}{r}M \\
\text { kno }\end{array}$ & & $\begin{array}{l}\text { Business } \\
\text { knowledge }\end{array}$ \\
\hline & \multicolumn{4}{|c|}{ Analyse, plan } & \multicolumn{4}{|c|}{$\begin{array}{l}\text { Strategise, problem solve, } \\
\text { communicate }\end{array}$} & \multicolumn{4}{|c|}{$\begin{array}{l}\text { Problem solve, develop } \\
\text { new businesses }\end{array}$} \\
\hline $\begin{array}{l}\text { Cultural } \\
\text { capital }\end{array}$ & \multicolumn{4}{|c|}{$\begin{array}{c}\text { Entrepreneurial } \\
\text { Determination, self belief, } \\
\text { optimism }\end{array}$} & \multicolumn{4}{|c|}{$\begin{array}{c}\text { Entrepreneurial } \\
\text { Determination, self belief, problem } \\
\text { solving, energy }\end{array}$} & \multicolumn{4}{|c|}{$\begin{array}{c}\text { Entrepreneurial \& Affiliate } \\
\text { Problem solving, energy, creativity }\end{array}$} \\
\hline $\begin{array}{l}\text { Social } \\
\text { capital }\end{array}$ & \multicolumn{2}{|c|}{$\begin{array}{c}\text { Trust } \\
\text { Introductions, } \\
\text { credibility } \\
\end{array}$} & \multicolumn{2}{|c|}{$\begin{array}{l}\text { Information } \\
\text { Markets }\end{array}$} & \multicolumn{2}{|c|}{$\begin{array}{l}\text { Trust } \\
\text { Introductions, } \\
\text { credibility }\end{array}$} & \multicolumn{2}{|c|}{$\begin{array}{c}\text { Promotion } \\
\text { Product/service } \\
\text { Feedback }\end{array}$} & \multicolumn{2}{|c|}{$\begin{array}{l}\text { Promotion } \\
\text { Product/service } \\
\text { Feedback }\end{array}$} & \multicolumn{2}{|c|}{$\begin{array}{l}\text { Information } \\
\text { New market } \\
\text { opportunities }\end{array}$} \\
\hline
\end{tabular}

Figure 2. IIE immigrant entrepreneurship process: forms of capital use 
of immigrant entrepreneurs. Social capital encompasses not only the networked and networking aspects of Granovetter's (1985) concept of embeddedness, but also the redundancy of networks and the strength of weak ties. Each of these aspects was significant, but especially at the critical second LTBV stage. The forms of symbolic capital also sit compatibly with the agentic and structural aspects of Waldinger, Aldrich and Ward's (1988) interactive theory of ethnic entrepreneurship. Symbolic capital also incorporates aspects of Volery's (2007) enhanced interactive ethnic entrepreneurship framework, particularly in relation to human and cultural capital. As symbolic capital theory conceptualizes the relationship between the material and symbolic, it elucidates how the material structural obstacles encountered by participants such as LTBV requirements, were resolved by the appropriateness and adequacy of their symbolic capital resources.

\section{The Preparation Stage}

Two key tasks in the preparation phase for moving to New Zealand were first, identifying an appropriate visa, and subsequently completing the detailed LTBV application. Neither task was straightforward. The LTBV application included preparing a business plan to demonstrate:

- sufficient financial capital to finance the business proposal;

- sufficient funds to support the applicant (and the applicant's family members) until the proposed business could sustain them;

- adequate business-related experience and, if necessary, evidence of obtaining professional or occupational registration in New Zealand;

- knowledge of the proposed business and the New Zealand business environment;

- the benefits of the proposed business to New Zealand.

Adequate financial capital was essential for participants to fund their proposed businesses, make exploratory visits to New Zealand, support dependents until the business became sustainable, pay costs and fees of the LTBV application and pay for the professional services of agents, accountants and lawyers whose services might have been contracted. Participants often demonstrated creative financial solutions. For example, New Zealand business partners were sought to help finance proposed endeavors and franchises were also seen as a cost effective entry point.

In the preparation phase, participants needed three knowledge dimensions of human capital: specialist knowledge of their industry; knowledge of the market in New Zealand; and general business knowledge. Evidence of their knowledge was demonstrated in their applications and through their curriculum vitae and business plans. It was also demonstrated through their analytical and planning skills. Technical and search skills were also invaluable at this stage.

Entrepreneurial cultural dispositions were also crucial. Most evident was self-belief and self confidence which, when coupled with positive and optimistic attitudes, led applicants to believe in their abilities to overcome obstacles and resolve any issues. Perhaps most significant was their determination to succeed. This was shown by participants who, for example, persevered despite receiving poor or even incorrect advice from government officials. Adaptability was demonstrated, for example, by those who had to change or modify their business plans and cope with delays in securing their visa. Optimism was demonstrated by those who, for example, were initially rejected during the 
process, but persisted because they believed in their ultimate success. Participants also persistently adapted when applications were lost or officials provided misinformation, circumstances changed and when qualifications and experience from another country were not acknowledged in New Zealand. Despite obstacles, participants commented on relishing the challenges of resolving problems as part of the pleasure of undertaking the entrepreneurial journey.

Networked social capital was less significant at the preparation stage than entrepreneurial or human capital. Although local market information was essential, social networks tended to be undeveloped. Instead, participants often recruited mentors to obtain local, sometimes privileged information. Recruiting an appropriate mentor relied on human capital to identify the right person, plus the social skills to develop the relationship. Inadequate knowledge of local conditions could impact on the granting of a LTBV, as applicants needed to recognize that information from the internet required supplementary local knowledge.

\section{The Implementation Stage}

Establishing a business is a complex, multi-faceted, demanding process for business people operating in a familiar environment. Yet newly arrived IIEs had to implement their business plans in an unfamiliar business and cultural environment in the very short period of nine months. All IIEs interviewed made reference to the intense time pressure they were working under at this stage. As Figure 2 indicates, over this period IIEs had to have adequate financial capital to support themselves and their families and set up their businesses. Almost all participants mentioned finding ways to minimize costs, including working hard and for long hours, and often doing things themselves rather than employing labor.

The time pressured implementation stage required the engagement of all forms of symbolic capital for applicants to be successful, but two dimensions of cultural capital were crucial for success. The first, entrepreneurial cultural capital, was essential to business implementation in such a short time period. If the participants had lacked the motivation or desire to problem-solve, or had wavered in their determination to overcome obstacles, then it is unlikely that they would have succeeded, regardless of their levels of human and social capital. Despite detailed planning, participants encountered unanticipated structural barriers, such as codes of compliance requirements, forcing them to constantly problem-solve. The characteristic dispositions of entrepreneurial cultural capital - self-belief, determination, optimism, adaptability, autonomy, pride in problemsolving and outgoingness - consistently emerged participants' comments on the second stage. While visible networking processes and documented business plans, budgets, services and products provide tangible evidence of social and human capital activity, intangible entrepreneurial cultural capital was the key factor critical to success. This applied to all participants, despite the diversity of their backgrounds, professions and settlement locations.

The second crucial dimension of cultural capital was affiliate cultural capital, acquired through membership of professional organizations. These ranged from organizations whose members held tertiary qualifications and were subject to codes of conduct, to more informal business arrangements. The value of affiliate cultural capital to participants was the speedy access and credibility it conferred on them post-arrival, enabling 
them to cloak themselves in the integrity of an organization's reputation. Astutely exploiting their affiliate cultural capital to obtain trustworthy introductions to professional, ethnic and social networks, they implemented their purposeful, strategic networking plans. The resulting social capital enhanced participants' credibility and promoted their businesses, while enabling access to new information. Networking behavior dramatically increased at the implementation stage, reflecting systematic, instrumental networking strategies undertaken to establish credibility, promote the business cost effectively and elicit feedback.

\section{The Consolidation/ Expansion Stage}

The task faced by LTBV holders in this final stage of the entrepreneurial process was to consolidate the financial sustainability of their businesses in order to qualify for residence. An application for residence required verifiable, reliable evidence from an independent agency to show that a legally compliant business had been established, which benefited New Zealand (New Zealand Immigration Service, 2006). Passive or speculative involvement was specifically excluded, as applicants were required to be actively involved in the management and operation of their New Zealand business which they established or purchased. Reliable, independent evidence could include a certificate of incorporation, audited accounts, or GST and other tax records. Benefits to New Zealand's economic growth might include evidence of the introduction of new technology, management or technical skills, products, services, export markets or increased employment (New Zealand Immigration Service, 2006).

Over half the participants claimed to be intent on expanding their businesses. The greatest problem faced in this regard was in the recruitment and retention of suitable staff. Some participants recruited internationally to solve staffing problems. However, apart from staffing issues, few other problems arose at this stage. The participants' instrumental networking strategies initiated during the implementation stage continued during this third stage and fulfilled three purposes: to earn and retain trust and respect; to promote the business and strengthen relationships with clients; and to obtain information.

Entrepreneurial capital, evident in the earlier stages, was similarly important when participants were expanding their businesses. Once established, their characteristic selfconfidence and determination motivated a search for new business challenges. Their optimism in their ability to overcome obstacles was justified as they survived and succeeded. The participants' adaptability continued to be demonstrated in their newest enterprises while maintaining their existing businesses. The participants clearly achieved the objectives of New Zealand's business immigration policy. Through their extensive deployment of human capital, plus their innovations, they contributed to creating or expanding businesses in New Zealand by introducing new technologies, expertise, international connections and creating employment. Moreover, for at least a third of the participants, international business connections were actively functioning in parallel with their LTBV enterprise. 


\section{CONCLUSIONS}

This article presents a model for the successful adaptation of IIEs to their selected host country. Developed from a study of IIEs to New Zealand, the model demonstrates the forms of capital required to satisfy stringent, time-related visa conditions for IIEs who gained New Zealand residency through setting up and running a successful business. The IIE adaptation model is broken down into three fundamental stages: the preparation stage; the implementation stage; and the consolidation/expansion stage. These stages apply broadly across the entrepreneurial process regardless of the characteristics of individual entrepreneurs, the businesses in which they are involved, or whether or not they need to fulfill any specific conditions, like those pertaining to the LTBV. We have argued that the model presented can be used to analyze the successful adaptation of all successful immigrant entrepreneurs to their host country and could also be applied in contexts well beyond New Zealand to help explain successful entrepreneurship.

Several conclusions can be drawn from this study. First, that IIEs are a distinct niche category within immigrant entrepreneurship scholarship. Second, a consideration of the success of IIEs requires exploration into forms of capital beyond economic capital. In this regard Bourdieu's (1986) concept of symbolic capital is useful to encompass the range of human, cultural and social capital resources essential to IIE success. Third, the study has shown that distinctive dimensions of each form of symbolic capital are employed in different ways at different stages of the entrepreneurial process. Motivating the immigrant entrepreneurial enterprise was the participants' determined energy, representing their embodied entrepreneurial cultural capital. Self-confidence and determination came through again in the relish shown in taking up new business challenges. Their optimism in their ability to overcome obstacles was justified as they survived and succeeded. The participants' adaptability continued to be demonstrated in their newest enterprises while maintaining their existing businesses.

As a small scale case study, the research on which this article is based could be criticized for its lack of generalizability and statistical rigor. However, in-depth, postpositivist, qualitative approaches need to be considered on their own terms, rather than from an alternative epistemological position. The value of this kind of study lies in the depth of insights garnered. However, a limitation of this study is the lack of robust representation of participants for whom English is a second language. The small sample size could also be viewed as a limitation. However, with the diversity within the sample in terms of nationality, professional backgrounds, types of business and settlement locations, there was such a strong consistency in the patterns which emerged that we were assured of the robust nature of the results.

Further research on IEEs could be valuable for immigrant entrepreneurship scholarship internationally. Policy focused research could inform immigration policy. In New Zealand and elsewhere ${ }_{\mathbf{L}}$ further research into the experience of IIEs whose first language differs from that of the host country. Comparative studies of IIEs across countries seeking these immigrants would also be valuable.

IIEs are recognized as a valuable international resource to be competed for. Comprehensive knowledge of the resourcing factors influencing their successful business establishment should enable countries to target and recruit IIEs more effectively. As 
effective immigration policies seek to balance global pressures of migrant numbers and international obligations against internal national economic and political demands, the results of this study may resonate in similar immigration jurisdictions.

\section{REFERENCES}

Adam, C. S., \& Bevan D. L. (2005). Fiscal deficits and growth in developing countries. Journal of Public Economics, 4, 571-597.

Alesina, A., M. de Broeck, Prati, A., \& Tabellini, G. (1992). Default risk on government debt in OECD Countries. Economic Policy: A European Forum, October, 427-463.

Aldrich, H. E., \& Waldinger, R. (1990). Ethnicity and entrepreneurship. Annual Review of Sociology, 16, 111-135.

Badkar, J. (2006). Life in New Zealand: Settlement experiences of skilled migrants: Results from 2005 survey. Wellington: Department of Labour

Bascand, G. (2008). Longitudinal immigration survey: New Zealand (LisNZ) - Wave 1. Wellington: Statistics, New Zealand.

Basu, A. (2004). Entrepreneurial aspirations among family business owners. An analysis of ethnic business owners in the UK. International Journal of Entrepreneurial Behaviour \& Research, 10(1/2), 12-33.

Becker, G. S. (1975). Human capital. New York, NY: National Bureau of Economic Research.

Boissevan, J., Blaschke, J., Grotenbreg, H., Joseph, I., Light, I., Sway, M., et al. (2006). Ethnic entrepreneurs and ethnic strategies. In R. Waldinger, H. Aldrich \& R. Ward (Eds.), Ethnic Entrepreneurs. Newbury Park: Sage Publications.

Bolton, B., \& Thompson, J. (2004). Entrepreneurs: Talent, temperament, technique (2nd ed.). Oxford: Elsevier Butterworth-Heinemann.

Bourdieu, P. (1986). The forms of capital (R. Nice, Trans.). In J. G. Richardson (Ed.), Handbook of theory and research for the sociology of education. New York: Greenwood.

Brubaker, R. (1985) Rethinking classical theory: The sociological vision of Pierre Bourdieu. Theory and Society, 14(6), 745-775.

Brzozowski, J., Cucculelli, M., \& Surdej, A. (2014). Transnational ties and performance of immigrant entrepreneurs: the role of home-country conditions. Entrepreneurship \& Regional Development, 26(7-8), 546-573.

Castles, S., \& Miller, M. J. (2009). The age of migration: International population movements in the modern world (4th ed. Vol. 1). New York: Palgrave Macmillan.

Coleman, J. (1988). The creation and destruction of social capital. Notre Dame Journal of Law, Ethics and Public Policy, 3, 375-404.

Collins, J. (2004). Analysing immigration with one eye shut: The inherent inability of neoclassic economics to assess all aspects of the immigration and settlement experience. Ninth International Metropolis Conference 27 October-1 November: Geneva.

Collins, J. (2008). Immigrant entrepreneurs in Australia: Regulations and responses. In C. R. Oliveira \& J. Rath (Eds), Migrações Journal - Special Issue on Immigrant Entrepreneurship, October 2008, n. 3, Lisbon: ACIDI, 49-59.

Collis, J., \& Hussey, R. (2009). Business research: A practical guide for undergraduate and post graduate students (3rd ed.). Basingstoke: Palgrave/Macmillan. 
Cruickshank, P. (2013). Establishing a business in Aotearoa New Zealand: Cultural, human and social capital resources of intentional immigrant entrepreneurs. (Unpublished doctoral dissertation). Massey University, Auckland, New Zealand.

Curci, R., \& Mackoy, R. (2010). Immigrant business enterprises: A classification framework conceptualization and test. Thunderbird International Business Review, 52(2), 107-121.

Dana, L. (Ed.). (2007). Handbook of research on ethnic minority entrepreneurship. Cheltenham: Edward Elgar.

Denzin, N. K., \& Lincoln, Y. S. (2005). The handbook of qualitative research (3rd ed.). Thousand Oaks: Sage Publications.

Department of Labour (2004). Migration trends 2003/2004). Wellington: Department of Labour.

Department of Labour (2005). Migration trends 2004/2005. Wellington: Department of Labour.

Frederick, H. H., Kuratko, D. F., \& Hodgetts, R. M. (2007). Entrepreneurship: Theory, process, practice (Asia-Pacific Edition ed.). Melbourne: Thomson.

Granovetter, M. (1985). Economic action and social structure: The problem of embeddedness. American Journal of Sociology, 91(3), 481-510.

Hiebert, D. (2008). Big potential, small reward? Business Class immigration to Canada. In C. R. Oliveira \& J. Rath (Eds.), Migrações Journal - Special Issue on Immigrant Entrepreneurship, October 2008, n. 3, Lisbon: ACIDI, 31-47.

Kloosterman, R. (2000) Immigrant entrepreneurship and the institutional context: A theoretical exploration. In J. Rath (Ed.), Immigrant businesses. Basingstoke: Macmillan Press.

Kloosterman, R., \& Rath, J. (2001). Immigrant entrepreneurs in advanced economies: mixed embeddedness further explored. Journal of Ethnic and Migration Studies, 27(2), 189-202.

Kloosterman, R., \& Rath, J. (2003). Immigrant entrepreneurs:Introduction. In R. Kloosterman \& J. Rath (Eds.), Immigrant entrepreneurs: Venturing abroad in the age of globalisation. Oxford: Berg.

Kloosterman, R., van der Leun, J., \& Rath, J. (1999). Mixed embeddedness:(in)formal economic activities and immigrant businesses in the Netherlands. International Journal of Urban and Regional Research, 23(2), 252-267.

Ley, D. (2006). Explaining variations in business performance among immigrant entrepreneurs in Canada. Journal of Ethnic \& Migration Studies, 32(5), 743-764.

Light, I. (2004). The ethnic ownership economy. In C. H. Stiles \& C. Galbraith (Eds), Ethnic Entrepreneurship: Structure \& Process, 4, Amsterdam: Elsevier, 3-44.

Loury, G. C. (1977). A dynamic theory of racial income differences. In P.A Wallace (Ed), Women minorities and employment discrimination. Lexington, MA: Lexington Books.

Loury, G. C. (1981). Intergenerational transfers and the distribution of earnings. Econometric, 49, 843-867.

Marger, M. N. (2001a). Social and human capital in immigrant adaptation: the case of Canadian business immigrants. Journal of Socio-Economics, 30(2), 69-170.

Marger, M. N. (2001b). The use of social and human capital among Canadian business immigrants. Journal of Ethnic \& Migration Studies, 27(3), 439-453.

Marger, M. N. (2006). Transnationalis or assimilation? Patterns of sociopolitical adaptation among Canadian business immigrants. Ethnic and Racial Studies, 29(5), 882-900.

Merwood, P. (2006). Migration trends 2005/06. Wellington: Department of Labour.

Ndofor, H. A., \& Priem, R. L. (2011). Immigrant entrepreneurs, the ethnic enclave strategy, and venture performance. Journal of Management, 37(3), 790-818. 
New Zealand Department of Labour (2012). Migration Trends and Outlook 2011-2012. Wellington: Department of Labour.

New Zealand Immigration Service (2002). Business immigration: The evaluation of the 1999 Business Immigration Policy. Wellington: New Zealand Immigration Service, Department of Labour.

New Zealand Immigration Service (2006). Residence. Wellington: New Zealand Immigration Service.

Perreault, C., Brenner, G. A., Menzies, T. V., Filion, L. J., \& Ramangalahy, C. (2003). Social capital and ethnic business performance: Entrepreneurs from four ethnic groups in Canada. Montreal: Babson College-KauffmanFoundation Entrepreneurship Research Conference (BCKERC) 115.

Portes, A. (1998). Social capital: Its origins and applications in modern sociology. Annual Review of Sociology, 24, 1-24.

Putnam, R. D. (1995). Bowling alone: America's declining social capital. Journal of Democracy, 6(1), 65-78.

Putnam, R. D. (2000). The prosperous community: Social capital and public life. The American Prospect, 13(Spring), 35-42.

Rath, J. (Ed.) (2000). Immigrant businesses: The economic, political and social environment. Basingstoke: Macmillan Press, Great Britain-St Martin's Press Inc, USA.

Saxenian, A. (1999). Silicon Valley's new immigrant entrepreneurs. San Francisco: Public Policy Institute of California.

Saxenian, A. (2002). Silicon Valley's new immigrant high-growth entrepreneurs. Economic Development Quarterly, 16(20), 20-31.

Seidman, I. (1991). Interviewing as qualitative research: A guide for researchers in education and the social Sciences, New York: Teachers College Press, Columbia University.

Sequeira, J. M., \& Rasheed, A. A. (2004). The role of social and human capital in the start-up and growth of immigrant businesses. In C. H. G. Stiles, Craig, S. (Eds.), Ethnic entrepreneurship: Structure and pocess (pp. 77-94). Oxford: Elsevier Limited.

Statistics New Zealand (2014). Half a million Aucklanders born overseas. http://www.stats.govt.nz

Volery, T. (2007). Ethnic entrepreneurship: A theoretical framework. In L.-P. Dana (Ed.), Handbook of research on ethnic minority entrepreneurship. Cheltenham: Edward Elgar.

Waldinger, R., \& Aldrich, H. (2006). Trends in ethnic businesses in the United States. In J. H. S. II (Ed.), Ethnic entrepreneurs (pp. 49-78). Newbury Park: Sage Publications.

Waldinger, R., Aldrich, H., \& Ward, J. L. (Eds.) (2006). Ethnic entrepreneurs :Immigrant business in industrial societies, Newbury Park: Sage Publications.

Wallis, R. (2006). Skilled migrants in New Zealand: A study of settlement outcomes. Wellington: Department of Labour. 


\section{Authors}

The contribution of co-authors is equal and can be expressed as $50 \%$ each of the authors.

\section{Prue Cruickshank}

Lecturer in Communication Studies, Unitec, Auckland, New Zealand. PhD in Sociology from Massey University, Auckland, New Zealand.

\section{Ann Dupuis}

Associate Professor of Sociology and Regional Director of the College of Humanities and Social Sciences, Massey University, Albany, New Zealand. PhD in Sociology from the University of Canterbury, Christchurch, New Zealand.

Correspondence to:

Prof. Ann Dupuis, PhD

Regional Director, College of Humanities and Social Sciences

Massey University

Private Bag 102904, North Shore

Auckland 0745, New Zealand

+6494140800 ext. 43470

a.dupuis@massey.ac.nz

\section{Acknowledgementsand Financial Disclosure}

The authors would like to thank the anonymous referees for their valuable comments.

\section{Copyright and License}

This article is published under the terms of the Creative Commons

Attribution - NonCommercial - NoDerivs (CC BY-NC-ND 3.0) License

http://creativecommons.org/licenses/by-nc-nd/3.0/

Published by the Centre for Strategic and International Entrepreneurship - Krakow, Poland 